\title{
THE STRUCTURAL, MORPHOLOGICAL AND OPTICAL STUDY OF PURE AND W-DOPED TIO2 NANO PARTICLES AND ITS APPLICATION TO ANTIMICROBIAL ACTIVITY
}

\author{
K. Manikandan ${ }^{1 *}$, A. Jafar Ahamed ${ }^{2}$, N. Jayakumar ${ }^{3}$ \\ ${ }^{1}$ Department of Chemistry, Velalar College of Engineering and Technology (Autonomous), \\ Erode-638 012, India. \\ ${ }^{2}$ PG and Research Department of Chemistry, Jamal Mohamed College (Autonomous), \\ Trichy-620 020, India. \\ ${ }^{3}$ Department of Chemistry, Sri Vasavi College, Erode - 638316 , India.
}

\begin{abstract}
In this research work, the effect of tungsten-doping on the crystal structure, morphology and antimicrobial of titanium dioxide nanoparticles were studied. The pure and different weight \%

of tungsten doped $\mathrm{TiO}_{2}$ nanoparticles were synthesized by sol-gel method and calcinated at $600^{\circ} \mathrm{C}$ for $5 \mathrm{~h}$. The synthesised products have been characterized by X-ray Diffraction studies (XRD), Field Emission Scanning Electron Microscopy (FESEM), Energy Dispersive X-ray analysis (EDXA), Ultraviolet-Visible Diffuse Reflectance Spectroscope (UV-Vis), Photoluminescence Spectra (PL), High Resolution Transmission Spectroscopy (HRTEM) and Fourier Transform Infra Red Spectroscopy (FT-IR). XRD pattern of pure $\mathrm{TiO}_{2}$ and $1 \mathrm{wt} \% \quad \mathrm{~W}$-doped $\mathrm{TiO}_{2}$ nanoparticles confirms the anatase structure and increase in the $\mathrm{W}$-doping changes the phase of $\mathrm{TiO}_{2}$ to rutile. Average crystallite size of synthesized nanoparticles was determined using the Debye-Scherrer formula. The crystallite size obtained for pure $\mathrm{TiO}_{2}$ is $37 \mathrm{~nm}$ and W-doped $\mathrm{TiO}_{2}$ is $28 \mathrm{~nm}, 34 \mathrm{~nm}$ and $33 \mathrm{~nm}$. The FESEM images show the agglomerated particles of spherical-like morphology. Optical property and direct bandgap of pure and $\mathrm{W}$-doped $\mathrm{TiO}_{2}$ nanoparticles also further characterised by UV-Vis Spectroscopy. The images of HRTEM clearly confirm that particles present in the W-doped $\mathrm{TiO}_{2}$ powdered sample is nanosized particles. The Kirby Bauer Agar Well Diffusion Assay method was employed to explore antimicrobial activity of nanosized pure and $\mathrm{W}$-doped $\mathrm{TiO}_{2}$ colloidal suspension against the test microorganisms two Gram positive bacteria (Staphylococcus aureus, Bacillus subtilis), two Gram negative Bacteria (Escherichia coli, Pseudomonas aeruginosa) and two fungi (Candida albicans, Aspergillus niger). It shows that the $\mathrm{W}$-doped $\mathrm{TiO}_{2}$ nanoparticles inhibited the multiplication and growth of the above mentioned test bacteria and fungi. Antimicrobial activity was found against all tested microorganisms which confirmed that $\mathrm{W}$-doped $\mathrm{TiO}_{2}$ nanoparticles possess high antimicrobial activity compared to pure $\mathrm{TiO}_{2}$ nanoparticles.
\end{abstract}

Keywords: Nanoparticles, Sol-gel method, XRD, HRTEM, Antimicrobial activity.

${ }^{*}$ Corresponding author. Tel:+91 4242244201; FAX:+914242244205.

Email address: chemmani03@gmail.com (K.Manikandan).

\section{. INTRODUCTION}

Titanium dioxide is used as an eco friendly photo catalyst. It is an inexpensive, easily available, nontoxicity and chemically stable one. However, $\mathrm{TiO}_{2}$ is used other than photocatalyst and this is used in catalyst support, photoconductors, solar cells, gas sensors, coatings etc. Now the scientist are focused in antimicrobial activity of $\mathrm{TiO}_{2}$ due to its rapid recombination of photo activated electrons and positive holes. Titanium dioxide present in three different crystalline phases: rutile, anatase, and brookite. Out of these three phases, Rutile phase is stable one compared to other two phases are in metastable. Anatase and rutile systems have tetragonal unit cells. The rutile phase possesses two $\mathrm{TiO}_{2} \mathrm{molecules}^{\circ}$

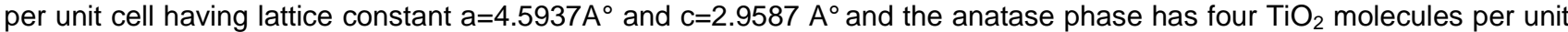
cell having lattice constant $a=3.7842 A^{\circ}$ and $c=9.5146 A^{\circ}$. Generally, the temperature of $\mathrm{TiO}_{2}$ nano crystal is increased to above $450^{\circ} \mathrm{C}[1,2]$ phase has been changed from anatase to rutile structure. Anatase and rutile phases of $\mathrm{TiO}_{2}$ nanocrystals are the two important photoactive polymorphic phases with the band-gap energy of $3.20 \mathrm{eV}$ and $3.02 \mathrm{eV}$ respectively [3]. Band gap value of the anatase phase is larger than that of the rutile phase, so the rutile phase properties are slightly better than the anatase phase properties in semiconducting performance [4]. In recent years, researcher's showed interest on the antimicrobial activity of doping of titanium dioxide with transition metals like tungsten, cobalt etc.

In this present study, synthesis of $\mathrm{W}$-doped $\mathrm{TiO}_{2}$ nanoranged particles by sol-gel method is to study the highest possible antimicrobial activity and it can be compared with pure $\mathrm{TiO}_{2}$ also prepared by solgel method. There are several methods such as sol-precipitation [5], ion-impregnation [6], hydrothermal synthesis [7], sol-gel synthesis [8] to available for obtain homogeneous doping of $\mathrm{W}$ in $\mathrm{TiO}_{2}$. But, Sol-gel is the most simple and sophisticated method among the various methods for producing nanoparticles. The preparation of thin film W-doped $\mathrm{TiO}_{2}$ nanoparticles in a colloidal state by sol-gel method which is used in antimicrobial coatings in water filters, leathers, textiles and medical devices. The prepared W-doped $\mathrm{TiO}_{2}$ nanoparticles were characterised by different techniques like X-ray diffraction (XRD), Field emission scanning electron microscopy (SEM), Energy dispersive X-ray Spectroscopy (EDXA), UV-Visible Diffuse Reflectance Spectroscopy (UV-Vis), Photoluminescence analysis (PL), Fourier Transform Infra Red spectroscopy (FTIR), and High resolution Transmission Electron Microscopy (HRTEM). The Kirby Bauer Agar Well Diffusion Assay method was employed to explore antimicrobial activity of nanosized pure and $\mathrm{W}$-doped $\mathrm{TiO}_{2}$ colloidal suspension against the test microorganisms two Gram positive bacteria (Staphylococcus aureus, Bacillus subtilis), two Gram negative Bacteria (Escherichia coli, Pseudomonas aeruginosa) and two fungi (Candida albicans, Aspergillus niger). It shows that the $\mathrm{W}_{-}-\mathrm{doped}^{\mathrm{TiO}} \mathrm{O}_{2}$ 
nanoparticles inhibited the multiplication and the growth of the above mentioned test bacteria and fungi. Antimicrobial activity was found against all tested microorganisms at a concentration range of $25 \mu \mathrm{g}, 50 \mu \mathrm{g}, 75 \mu \mathrm{g}$ and $100 \mu \mathrm{g}$ of pure $\mathrm{TiO}_{2}, 1$ wt $\%, 3$ wt $\%$ and $5 \mathrm{wt} \% \mathrm{~W}$-doped $\mathrm{TiO}_{2}$ solutions.

\section{EXPERIMENTAL}

\subsection{Materials}

Titanium isopropoxide (Sigma-Aldrich > $97 \%$ pure), sodium tungstate dihydrate (Merk, $98 \%$ pure), ethanol (Hayman (German) $99.99 \%$ pure), hydroxylamine hydrochloride (Sigma-Aldrich $99 \%$ pure) were used as precursor and is used without any further purification. Doubly distilled water was used for the whole synthesis process. Bacterial cultures such as Staphylococcus aureus, Bacillus subtilis, Escherichia coli, Aspergillus niger and fungus cultures such as Pseudomonas aeruginosa, Candida albicans were obtained from Eumic analytical Lab and Research Institute, Tiruchirappalli. Bacterial strains were maintained on nutrient agar slants (Hi media) at $4^{\circ} \mathrm{C}$.

\subsubsection{Physicochemical characterization}

The X-ray diffraction pattern analysis for pure $\mathrm{TiO}_{2}$ and doped $\mathrm{TiO}_{2}$ nanoparticles was recorded by $\mathrm{Lab} X$ XRD6000 Shimadzu model with $\mathrm{Cu}$-Ka radiation. The structure and morphology of the nanoparticles were investigated by Field Emission Scanning Electron Microscope (FESEM) using FEI Quanta FEG 200-High Resolution Scanning Electron Microscope. The absorption spectra and optical band gap of the $\mathrm{TiO}_{2}$ and doped $\mathrm{TiO}_{2}$ nanoparticles samples were measured by using UV-Vis Spectrophotometer (JASCO U-670 Spectrometer) and the alcohol as a solvent. The spectrum was recorded between $200-800 \mathrm{~nm}$. A Photoluminescence spectrum was recorded between $370-770 \mathrm{~nm}$ and it was carried out by using Horiba Jobnyvon model spectrophotometer and the alcohol is used as a solvent. FTIR absorption spectrum was recorded by JASCOFP8200 spectrophotometer. The particle size and lattice structure of the individual crystal was visualised by using High Resolution Transmission Electron Microscopy JE2100 (JEOL-200KV, LB6 filament) and EDXA analysis was carried out to find the composition of pure and doped $\mathrm{TiO}_{2}$ samples by using the detector attached with the same instrument.

\subsection{Synthesis of pure $\mathrm{TiO}_{2}$ and $\mathrm{W}$-doped $\mathrm{TiO}_{2}$ nanoparticles}

Pure titanium dioxide nanoparticles and $1 \mathrm{wt} \%, 3 \mathrm{wt} \%$ and $5 \mathrm{wt} \% \mathrm{~W}$-doped $\mathrm{TiO}_{2}$ nanoparticles were prepared by sol gel method [9]. For the preparation of $\mathrm{TiO}_{2}$ nanoparticles, aqueous solution of titanium (IV) isopropoxide was used as starting material. The sol was prepared by mixing titanium isopropoxide $(3 \mathrm{ml})$ with $24 \mathrm{ml}$ of ethanol and dissolved $1000 \mathrm{ml}$ of doubly distilled water at room temperature. The molar ratio of titanium isopropoxide and alcohol is 1:8 respectively. Hydroxylamine hydrochloride $0.694 \mathrm{~g}$ was dissolved in $100 \mathrm{ml}$ of deionised water and added gradually to the titanium isopropoxide sol. After stirring, an aqueous solution was centrifuged by using centrifuge machine. The precipitate obtained was dried at $105^{\circ} \mathrm{C}$ in hot air oven. It was then calcinated at $600^{\circ} \mathrm{C}$ in a muffle furnace for $5 \mathrm{~h}$ at a constant temperature rise of $2^{\circ} \mathrm{C} /$ minute. For the preparation of $1 \mathrm{wt} \%, 3 \mathrm{wt} \%, 5 \mathrm{wt} \% \mathrm{~W}$-doped $\mathrm{TiO}_{2}$ nanoparticles, aqueous solution of titanium (IV) isopropoxide was used as starting material. The sol was prepared by mixing titanium isopropoxide (3 ml) with $24 \mathrm{ml}$ of ethanol and dissolved $1000 \mathrm{ml}$ of double distilled water at room temperature. The molar ratio of titanium isopropoxide and alcohol is 1:8 respectively. Hydroxylamine hydrochloride $0.694 \mathrm{~g}$ was dissolved in $100 \mathrm{ml}$ of deionised water and added gradually to the titanium isopropoxide sol. For tungsten doping $1 \mathrm{wt} \%$ of sodium tungstate dihydrate solution was added into the $\mathrm{TiO}_{2}$ sol. The mixture of titanium (IV) isopropoxide and sodium tungstate dihydrate solutions were stirred for $3 \mathrm{~h}$ in the magnetic stirrer. After stirring, an aqueous solution was centrifuged by using centrifuge machine. The precipitate obtained was dried at $105^{\circ} \mathrm{C}$ in hot air oven. It was then calcinated at $600^{\circ} \mathrm{C}$ in a muffle furnace for $5 \mathrm{~h}$ at a constant temperature rise of $2^{\circ} \mathrm{C}$ /minute. Similarly $3 \mathrm{wt} \%$ and $5 \mathrm{wt} \% \mathrm{~W}$-doped $\mathrm{TiO}_{2}$ powders were prepared by the same procedure as mentioned in the above method.

\subsection{Antimicrobial activity}

\subsubsection{Preparation of culture media}

\subsubsection{Nutrient agar medium}

Nutrient agar medium of $\mathrm{pH} 7$ is one of the most commonly used medium for several routine bacteriological purposes. It was prepared by dissolving $5 \mathrm{~g}$ of peptone, $3 \mathrm{~g}$ of beef extract, $15 \mathrm{~g}$ of agar, $5 \mathrm{~g}$ of sodium chloride, $1.5 \mathrm{~g}$ of yeast extract in $100 \mathrm{ml}$ of distilled water, it is boiled to dissolve the medium completely and sterilized by autoclaving at $15 \mathrm{lb}$ psi pressure $\left(121^{\circ} \mathrm{C}\right)$ for $15 \mathrm{~min}$.

\subsubsection{Inoculum preparation}

Bacterial cultures were subcultured in liquid medium (Nutrient broth) at $37^{\circ} \mathrm{C}$ for $8 \mathrm{~h}$ and further used for the test $\left(10^{5}-10^{6} \mathrm{CFU} / \mathrm{ml}\right)$. The suspensions were prepared before the test was carried out.

\subsubsection{Assay of antimicrobial activity}

The nutrient broth was prepared, and bacterial and fungal colonies were inoculated into the broth culture and are used to assay the antimicrobial activity. 


\subsubsection{Inhibition zone assay (Kirby Bauer Agar Well Diffusion Assay)}

The nutrient agar medium was prepared and sterilized by autoclaving at $121^{\circ} \mathrm{C} 15 \mathrm{lbs}$ pressure for 15 min then aseptically poured the medium into the sterile petriplates and allowed to solidify the bacterial and fungal broth culture was swabbed on each petriplates using a sterile buds. Then, wells were made by well cutter. $1 \mathrm{wt} \%, 3 \mathrm{wt} \%$ and $5 \mathrm{wt} \% \mathrm{~W}$ doped $\mathrm{TiO}_{2}$ nanoparticles containing solutions were prepared dissolving $100 \mathrm{mg}$ of each in $100 \mathrm{ml}$ of DMSO solvent and from this stock solution, different concentrations of $1 \mathrm{wt} \%, 3 \mathrm{wt} \%$ and $5 \mathrm{wt} \% \quad \mathrm{~W}$-doped $\mathrm{TiO}_{2}$ nanoparticles calcinated at $600^{\circ} \mathrm{C}(25 \mu \mathrm{g}, 50 \mu \mathrm{g}, 75 \mu \mathrm{g}$ and $100 \mu \mathrm{g})$ solutions were taken for assay.

The antimicrobial activity of $1 \mathrm{wt} \%, 3 \mathrm{wt} \%$ and $5 \mathrm{wt} \% \mathrm{~W}$-doped $\mathrm{TiO}_{2}$ nanoparticles calcinated at $600^{\circ} \mathrm{C}$ were assayed against Staphylococcus aureus, Bacillus subtilis, Escherichia coli, Pseudomonas aeruginosa, Aspergillus niger and Candida albicans at $37^{\circ} \mathrm{C}$ for $24 \mathrm{~h}$. After incubation the plates were observed for the zone of inhibition.

The bacterial and fungal viable count was determined after $24 \mathrm{~h}$ by plating pure $\mathrm{TiO}_{2}, 1 \mathrm{wt} \%, \quad 3 \mathrm{wt} \%$ and $5 \mathrm{wt} \% \mathrm{~W}$ doped $\mathrm{TiO}_{2}$ nanoparticles calcinated at $600^{\circ} \mathrm{C}$ on nutrient agar plates and the number of colony forming units (CFU) which were counted by a viable count method. To control this, the bacterial and fungal cultures were incubated with Gentamicin. The sample material which has antimicrobial activity was identified by inhibited growth of the microorganisms and it is clearly seen as distinct zone of inhibition. The diameter of zone of inhibition was measured and expressed in millimetre [10]. The prepared $1 \mathrm{wt} \%, 3 \mathrm{wt} \%$ and $5 \mathrm{wt} \% \mathrm{~W}$-doped $\mathrm{TiO}_{2}$ nanoparticles calcinatedat $600^{\circ} \mathrm{C}$ nanoparticles with the sizes varied from 28 to $34 \mathrm{~nm}$. Kirby Bauer Agar Well Diffusion Assay test was conducted using 1 wt \%, 3 wt \% and 5 wt $\%$ W-doped $\mathrm{TiO}_{2}$ nanoparticles calcinated at $600^{\circ} \mathrm{C}$ nanoparticles and common antibiotic Gentamicin. The diameter of zone of inhibition for $1 \mathrm{wt} \%, 3 \mathrm{wt} \%$ and $5 \mathrm{wt} \% \quad \mathrm{~W}$-doped $\mathrm{TiO}_{2}$ nanoparticles calcinated at $600^{\circ} \mathrm{C}$ was compared to this antimicrobial agent [11]. The diameter of zone of inhibition for pure $\mathrm{TiO}_{2}$ at $600^{\circ} \mathrm{C}$ was also compared to this antimicrobial agent. To analyse the antimicrobial activity of $1 \mathrm{wt} \%, 3 \mathrm{wt} \%$ and $5 \mathrm{wt} \% \mathrm{~W}$-doped $\mathrm{TiO}_{2}$ nanoparticles calcinated at $600^{\circ} \mathrm{C}$ was obtained by the microemulsion method.

\section{Results and discussion}

\subsection{X-ray diffraction analysis (XRD)}
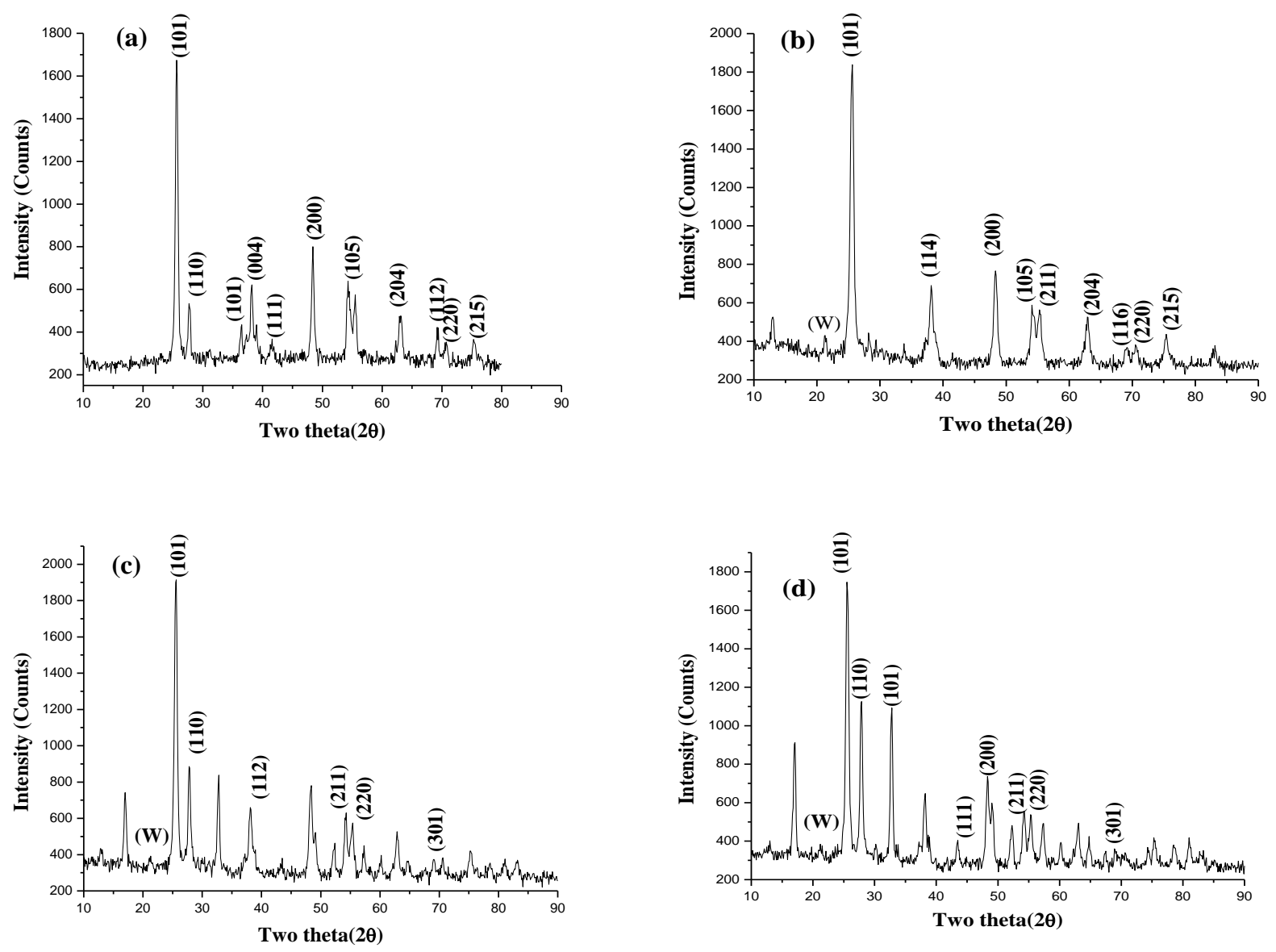

Figure 1 XRD pattern of (a) pure $\mathrm{TiO}_{2}$ (b) $1 \mathrm{wt} \% \mathrm{~W}$-doped $\mathrm{TiO}_{2}$ (c) $3 \mathrm{wt} \% \mathrm{~W}$-doped $\mathrm{TiO}_{2}$ and (d) $5 \mathrm{wt} \% \mathrm{~W}$ doped $\mathrm{TiO}_{2}$ calcinated at $600^{\circ} \mathrm{C}$ 
$X$ Ray Diffraction analysis was used to determine the crystalline structure and phase of the synthesised nanoparticles. Figure 1(a-d) shows the X Ray Diffraction patterns of pure and $\quad W$-doped $\mathrm{TiO}_{2}$ nanoparticles. The results shows that most of the peaks to pure and $1 \mathrm{wt} \% \quad$ W-doped $\mathrm{TiO}_{2}$ nanoparticles calcinated at $600^{\circ} \mathrm{C}$ confirms the formation of anatase phase by the existence of strong diffraction peaks at $2 \theta$ values of $25.3^{\circ}, 38.44^{\circ}, 48^{\circ}, 54^{\circ}, 55.07^{\circ}, 63^{\circ}, 69.23^{\circ}$, $70.89^{\circ}$, and $75.38^{\circ}$ corresponding to the crystal planes of (101), (112), (200) (105), (211) (204), (116), (220), and (215), respectively [JCPDS card no 21-1272] belonging to the tetragonal structure. The XRD diffraction patterns obtained for 3 wt $\%$ and $5 \mathrm{wt} \% \mathrm{~W}$-doped $\mathrm{TiO}_{2}$ nanoparticles are shown in the Figure 1(c and d). It showed the presence of characteristic rutile peaks at $2 \theta$ values of $27.4^{\circ}, 36.0^{\circ}, 39.1^{\circ}, 54.3^{\circ}$, and $64.0^{\circ} 2 \square$ to the crystal planes of (110), (101), (200), (211), and (002) respectively $\square \square$ (JCPDS: 88-1175) being a mix of anatase and rutile phase. The fineness peaks indicates that the nanosized materials were well crystallized. There are several studies reported $[12,13,14]$ that sol-gel sample of $\mathrm{TiO}_{2}$ should undergo a phase transformation from anatase to rutile during the higher calcinations (above $500^{\circ} \mathrm{C}$ ) temperature in general. Here, the results showed that major phase transformation from anatase to rutile takesplace with the increase of wt $\%$ of $\mathrm{WO}_{3}$, new peaks appeared at $2 \theta=20.45^{\circ}$ and $22.83^{\circ}$ (marked as $\mathrm{W}$ ), for the $\mathrm{W}$-doped $\mathrm{TiO}_{2}$. The new peaks may be attributable to a new component of $\mathrm{W}_{\mathrm{x}} \mathrm{Ti}_{1-\mathrm{x}} \mathrm{O}_{2}$. It has been observed by other researchers that, At high wt \% of tungsten doping $\left(5 \mathrm{wt} \%\right.$ ), retarded the phase transformation (up to $900^{\circ} \mathrm{C}$ ) $[15,7]$. But this experiment is not found in any retardant at the current level of doping (3 wt \% and $5 \mathrm{wt} \%$ ) [16] is due to $\mathrm{W}$ ions in $\mathrm{TiO}_{2}$ can either replace titanium ions to form $\mathrm{W}$ $\mathrm{O}$-Ti bonds or locate at interstitial sites.

The average particle size of pure $\mathrm{TiO}_{2}$ is $37 \mathrm{~nm}$ and $1 \mathrm{wt} \%, 3 \mathrm{wt} \%$ and $5 \mathrm{wt} \% \mathrm{~W}$-doped $\mathrm{TiO}_{2}$ powders are about $28 \mathrm{~nm}$, $34 \mathrm{~nm}$ and $33 \mathrm{~nm}$ respectively. The average particle sizes was calculated using the full-width at half maximum measurement at $2 \theta$ of the maximum diffraction peaks using the following Debye-Scherrer's formula,

\section{$\mathrm{D}=\mathrm{K} N / \beta \cos \theta$}

In this equation, $\mathrm{D}$ is the crystallite size, $\mathrm{K}$ the Scherrer constant usually taken as $0.89, \lambda$ the wavelength of the $\mathrm{X}$-ray radiation $(0.15418 \mathrm{~nm}$ for $\mathrm{Cu} \mathrm{K \alpha})$. Comparing the $\mathrm{XRD}$ patterns $\mathrm{W}$-doped $\mathrm{TiO}_{2}$, it appears that $\mathrm{W}$ loading does not influence the crystalline structure of $\mathrm{TiO}_{2}$.

\subsection{Field Emission Scanning Electron Microscope (FESEM)}

(a)

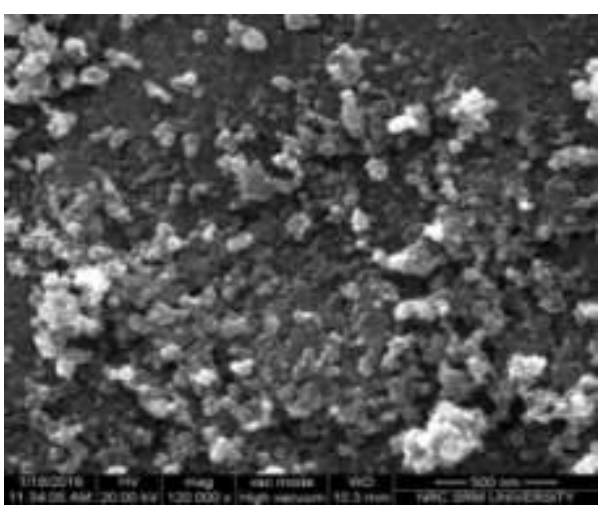

(c)

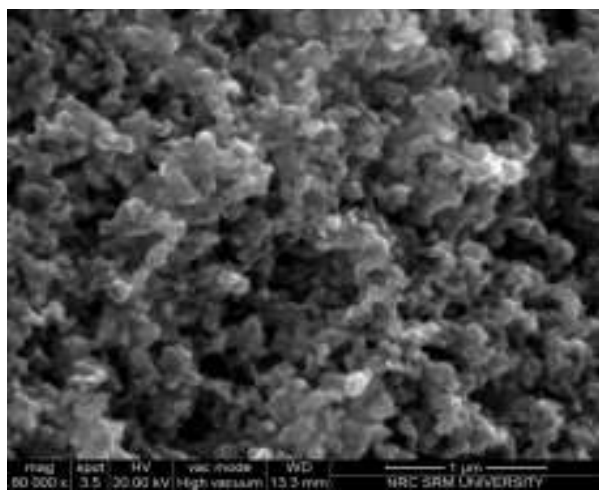

(b)

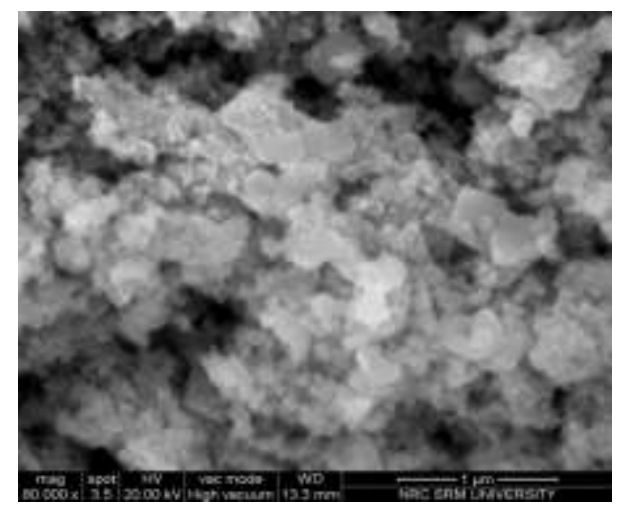

(d)

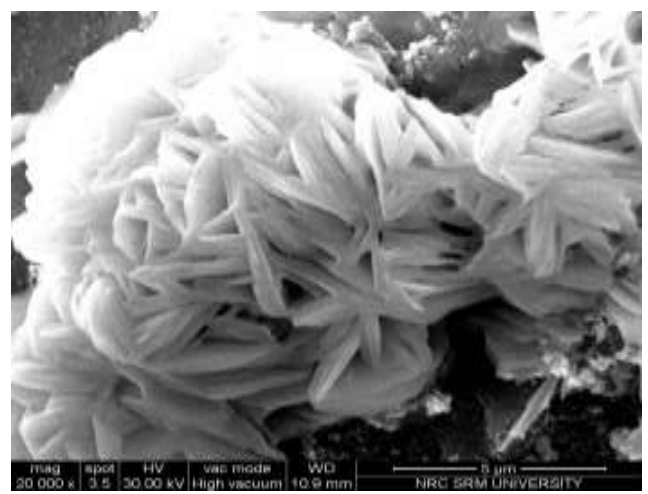

Figure 2 FESEM micrographs of (a) pure $\mathrm{TiO}_{2}$ (b) 1 wt \% W-doped $\mathrm{TiO}_{2}$ (c) 3 wt \% W-doped $\mathrm{TiO}_{2}$ and (d) 5 wt \% W-doped $\mathrm{TiO}_{2}$ calcinated at $600^{\circ} \mathrm{C}$ 
The FESEM images of pure and $\mathrm{W}$-doped $\mathrm{TiO}_{2}$ calcinated at $600^{\circ} \mathrm{C}$ are shown in Figure 2 (a-d). From the images, it can be confirmed that the average agglomerated particle size is nearly spherical and homogeneous particles. FESEM micrograph of $\mathrm{W}$-doped $\mathrm{TiO}_{2}$ nanoparticles shows that the surface morphology of the particles is nearly spherical with uniform sized particles and coherent together. However, the individual spherical particles are clearly seen due to the nanoclusters formed during the growth for $1 \mathrm{wt} \%, 3 \mathrm{wt} \% \mathrm{~W}$-doped $\mathrm{TiO}_{2}$. But it can be seen from the $5 \mathrm{wt} \% \mathrm{~W}$-doped $\mathrm{TiO}_{2}$ nanoparticles, nanorod type of nanoparticles were obtained. It can be seen that the average agglomerated particle size of $1 \mathrm{wt} \%, 3 \mathrm{wt} \% \mathrm{~W}$-doped $\mathrm{TiO}_{2}$ prepared by sol-gel method has no influence on the particle except $5 \mathrm{wt} \% \mathrm{~W}$-doped $\mathrm{TiO}_{2}$.

\subsection{Energy Dispersive Analysis by X-Rays (EDXA)}

(a)

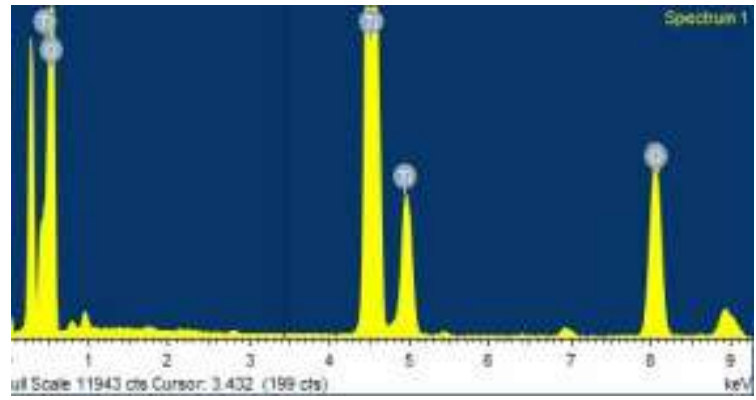

(c)

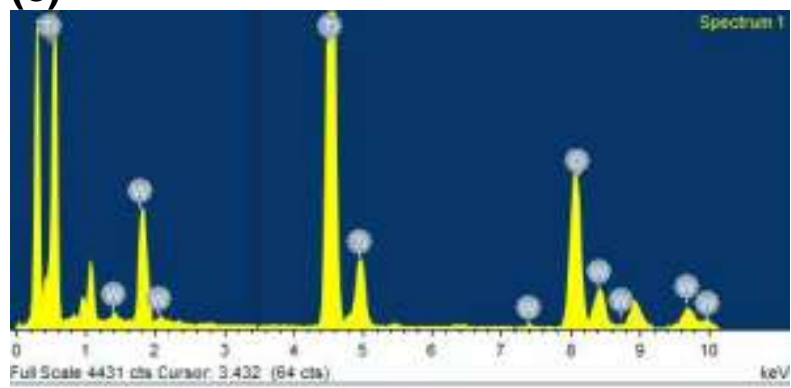

(b)

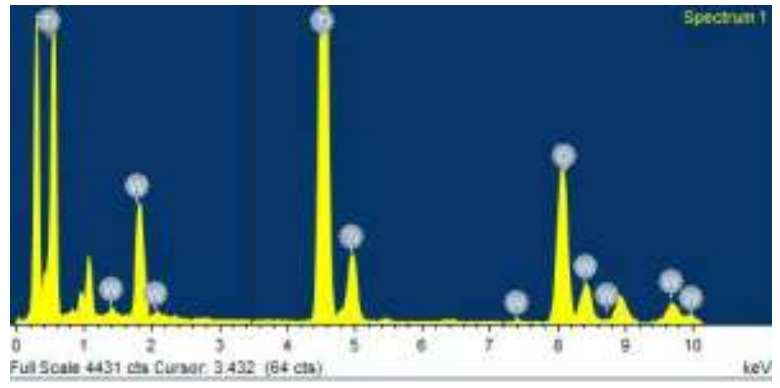

(d)

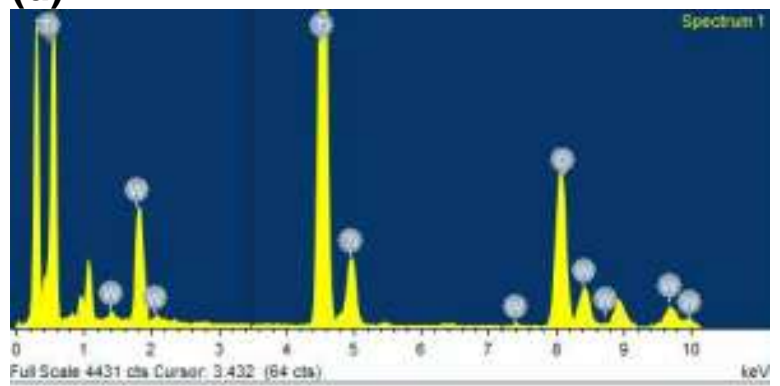

Figure 3 EDXA pattern of pure, 1 wt $\%, 3$ wt $\%$ and 5 wt $\%$ W-doped $\mathrm{TiO}_{2}$ nanoparticles calcinated at $600^{\circ} \mathrm{C}$

Analysis of EDXA is used to analyze the chemical composition of the prepared material. It is clear that from the figure $3(\mathrm{a}) \mathrm{TiO}_{2}$ is in pure form and free from any observable impurities. Figure 3 (b-d) also shows the EDXA of 1 wt \%, 3 wt $\%$ and 5 wt \% W-doped $\mathrm{TiO}_{2}$ samples, prepared by sol-gel method. EDXA shows only peaks of titanium, tungsten and oxygen elements. From the figure, it is clear that $\mathrm{W}$-doped $\mathrm{TiO}_{2}$ is free from impurities.

\subsection{UV-Visible diffuse reflectance spectra (UV-Visible spectra)}

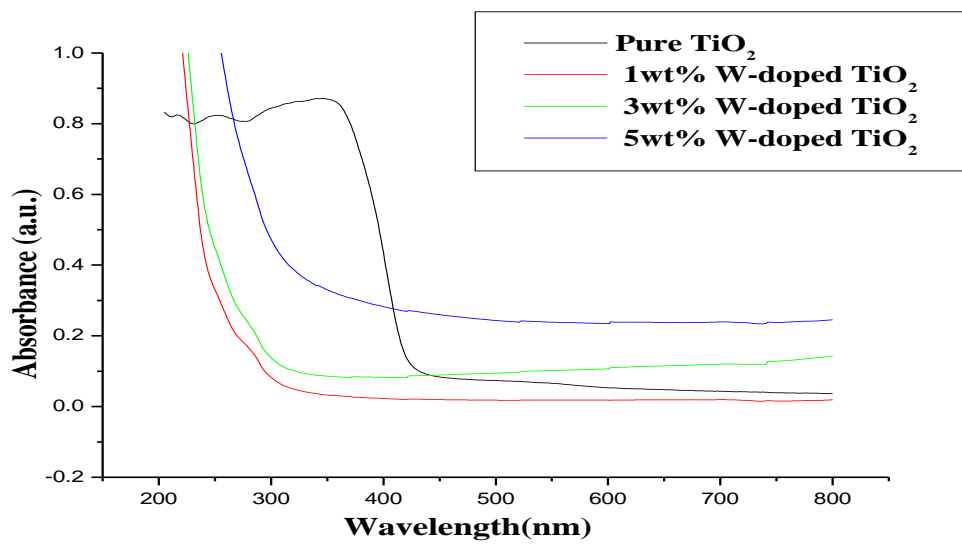

Figure 4 UV-Vis diffuse reflectance spectra of pure $\mathrm{TiO}_{2}, 1 \mathrm{wt} \%, 3$ wt $\%$ and 5 wt $\%$ of W-doped $\mathrm{TiO}_{2}$ calcinated at $600^{\circ} \mathrm{C}$ 
UV-Visible spectroscopy measurement was performed to explore the absorbance and band gap of pure and $1 \mathrm{wt} \%, 3 \mathrm{wt}$ $\%$ and $5 \mathrm{wt} \% \mathrm{~W}$-doped $\mathrm{TiO}_{2}$ nanoparticles. The optical absorbance spectra of pure and $\mathrm{W}$-doped $\mathrm{TiO}_{2}$ samples were recorded by a UV-Vis spectrophotometer in the range of $200-800 \mathrm{~nm}$ are shown in figure 4 . From the figure, it indicates that blue shift was observed for pure $\mathrm{TiO}_{2}$ compared with $\mathrm{W}$-doped $\mathrm{TiO}_{2}$ samples. The band edge absorption for pure $\mathrm{TiO}_{2}$ blue shifted with tungsten doping indicates that widening of the optical band gap of pure $\mathrm{TiO}_{2}$ [17]. The obtained results can be confirms the band gap value of $\mathrm{W}$-doped $\mathrm{TiO}_{2}(4.47 \mathrm{eV}, 3.96 \mathrm{eV}$ and $3.41 \mathrm{eV})$ larger than the pure $\mathrm{TiO}_{2}(2.86 \mathrm{eV})$.

But in the case of UV-Vis absorbance spectra of doped $\mathrm{TiO}_{2}, 1 \mathrm{wt} \% \mathrm{~W}$-doped $\mathrm{TiO}_{2}$ compared with other doped $(3 \mathrm{wt} \%$ and $5 \mathrm{wt} \%) \mathrm{TiO}_{2}$ samples observed redshift when increasing the doping concentration of tungsten. It can be seen that from the figure 4. Optical absorption edges are shifted to higher wavelength region (red shift) with increasing dopant tungsten [18]. This redshift may create consistent of the tungsten onto the $\mathrm{TiO}_{2}$ crystal lattice which creates impurity in the band gap [19] leading to reduction in the band gap energies [20]. The band gap of the samples can be determined by extrapolation of the absorption edge onto the $x$-axis and using the Planck's equation

$$
E_{g}=h C / \lambda
$$

Where $E_{g}$ is the energy gap of pure and doped $\mathrm{TiO}_{2}$ at absorption wavelength $\lambda$,

$$
\begin{gathered}
\mathrm{h} \text { is the Planck's constant, } \\
\mathrm{C} \text { is the velocity of light }
\end{gathered}
$$

The calculated bandgap values for pure $\mathrm{TiO}_{2}$ is $2.86 \mathrm{eV}$ and $\mathrm{W}$-doped nanoparticles values are $4.47 \mathrm{eV}, 3.96 \mathrm{eV}$ and $3.41 \mathrm{eV}$. From the bandgap values of $\mathrm{W}$-doping, decreases when increase the doping of $\mathrm{W}$ content which shift to the longer wavelength. This may be attributed to the new electronic states and are introduced in the middle of the $\mathrm{TiO}_{2}$ bandgap after doping the $\mathrm{W}$ atoms [18].

\subsection{Photoluminescence study (PL)}

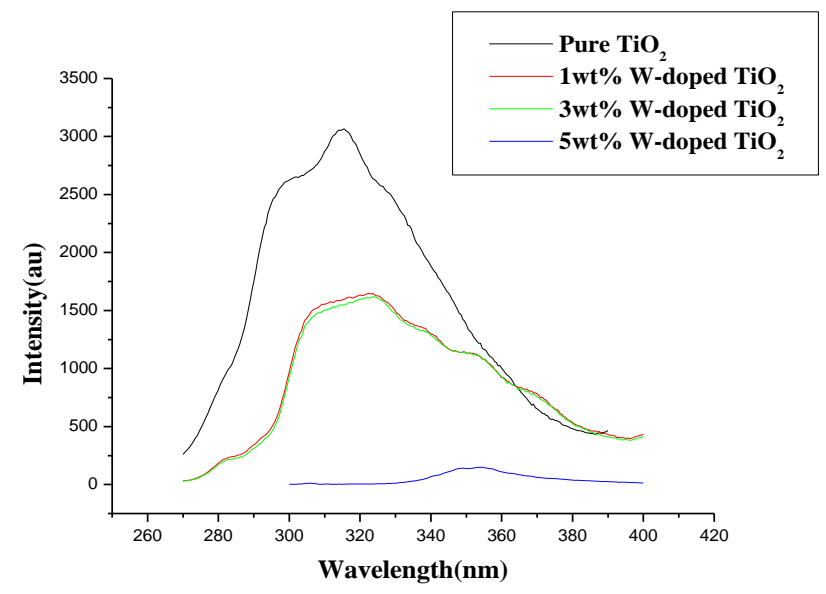

\section{Figure 5 Photoluminescence spectrum of pure $\mathrm{TiO}_{2}, 1$ wt \%, 3 wt $\%$ and $5 w t \%$ W-doped $\mathrm{TiO}_{2}$ samples calcinated at $600^{\circ} \mathrm{C}$}

Photoluminescence spectroscopy $(\mathrm{PL})$ is a useful method to find the efficiency of trapping of charge carrier, transfer and circumstances of electron-hole pairs in semiconductor particles. The excitation wavelength of the pure $\mathrm{TiO}_{2}$ is found to be at $325 \mathrm{~nm}$. Similarly, for other excitation wavelength of $\mathrm{W}$-doped $\mathrm{TiO}_{2}$ nanoparticles is observed at $325 \mathrm{~nm}, 325 \mathrm{~nm}$ and $355 \mathrm{~nm}$ which indicates that trapped electrons and oxygen vacancies. Photoluminescence spectra of pure $\mathrm{TiO}_{2}$ is greater than the PL intensity of $1 \mathrm{wt} \%, 3 \mathrm{wt} \%$ and $5 \mathrm{wt} \% \mathrm{~W}$-doped $\mathrm{TiO}_{2}$, which is due to a lower recombination rate of electrons and holes $[21,22]$ in the presence of light irradiation by the transition of energy levels between $\mathrm{WO}_{3}$ orbital and $\mathrm{TiO}_{2}$ orbital. It takesplace by photogenerated electrons and are transferred to $\mathrm{WO}_{3}$ conduction band from $\mathrm{TiO}_{2}$ conduction band and the holes accumulate in the $\mathrm{TiO}_{2}$ valence band which results in photogenerated electrons and holes are separated. The figure 5 shows the photoluminescence spectrum of pure and 1 wt $\%, 3 \mathrm{wt} \%$ and 5 wt $\% \mathrm{~W}_{\text {-doped }} \mathrm{TiO}_{2}$ nanoparticles which show that the position of the peaks is almost similar except the $5 \mathrm{wt} \% \mathrm{~W}$-doped $\mathrm{TiO}_{2}$ nanoparticles and the photoluminescence intensity of pure $\mathrm{TiO}_{2}$ is greater than the $\mathrm{PL}$ intensity of $\mathrm{W}$-doped $\mathrm{TiO}_{2}$. It indicates that the recombination of charge carriers is effectively reduced by the doping tungsten metal [23]. The peaks for the doped $\mathrm{TiO}_{2}$ shift to red direction and also this shift of emission peak towards longer wavelengths further supports the lowering of the band gap of $\mathrm{TiO}_{2}$ due to the tungsten doping treatment. 


\subsection{Fourier Transform Infrared Spectroscopy (FTIR)}

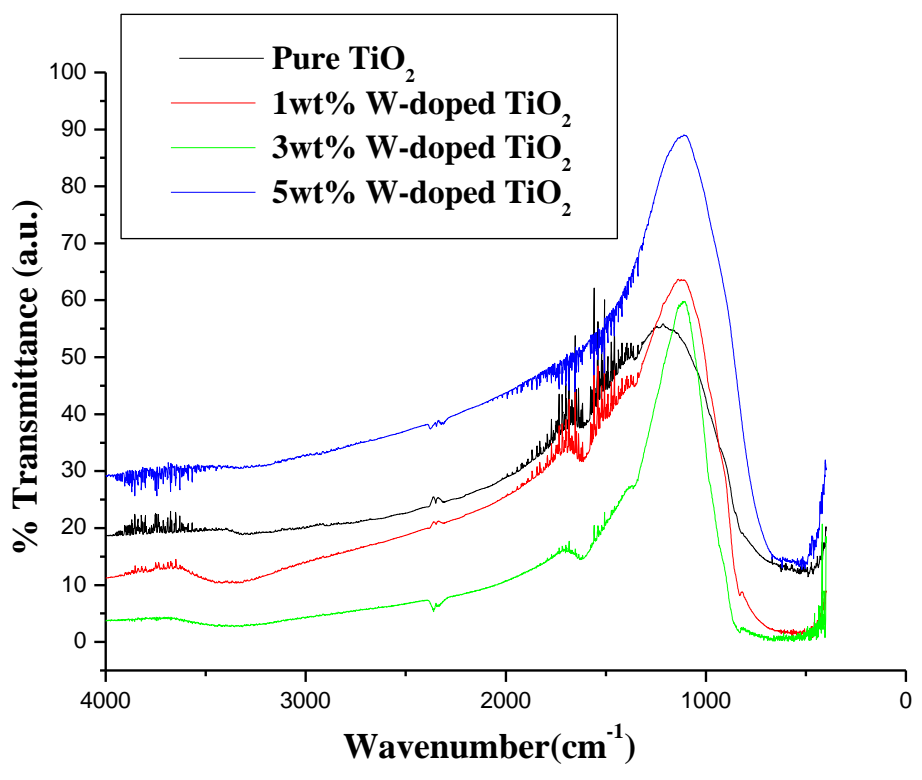

Figure 6 Fourier transforms infrared spectra of (a) pure $\mathrm{TiO}_{2}$, (b) 1 wt \% W-doped $\mathrm{TiO}_{2}$, (c) 3 wt \% Wdoped

$\mathrm{TiO}_{2}$ and (d) $5 \mathrm{wt} \% \mathrm{~W}$-doped $\mathrm{TiO}_{2}$ samples calcinated at $600^{\circ} \mathrm{C}$

IR spectra of pure and $\mathrm{W}$-doped $\mathrm{TiO}_{2}$ are shown in Figure 6. The absorption bands are shown in the region of 3300-3400 $\mathrm{cm}^{-}$for vibrations of $\mathrm{O}-\mathrm{H}$ and $1620-1630 \mathrm{~cm}^{-1}$ in the region indicates the bending vibrations of the molecules. The little difference of band around 450 to $800 \mathrm{~cm}^{-1}$ indicates the presence of Ti-O-W, compared to pure $\mathrm{TiO}_{2}$ [24].

\subsection{High Resolution Transmission Electron Microscopy (HRTEM)}

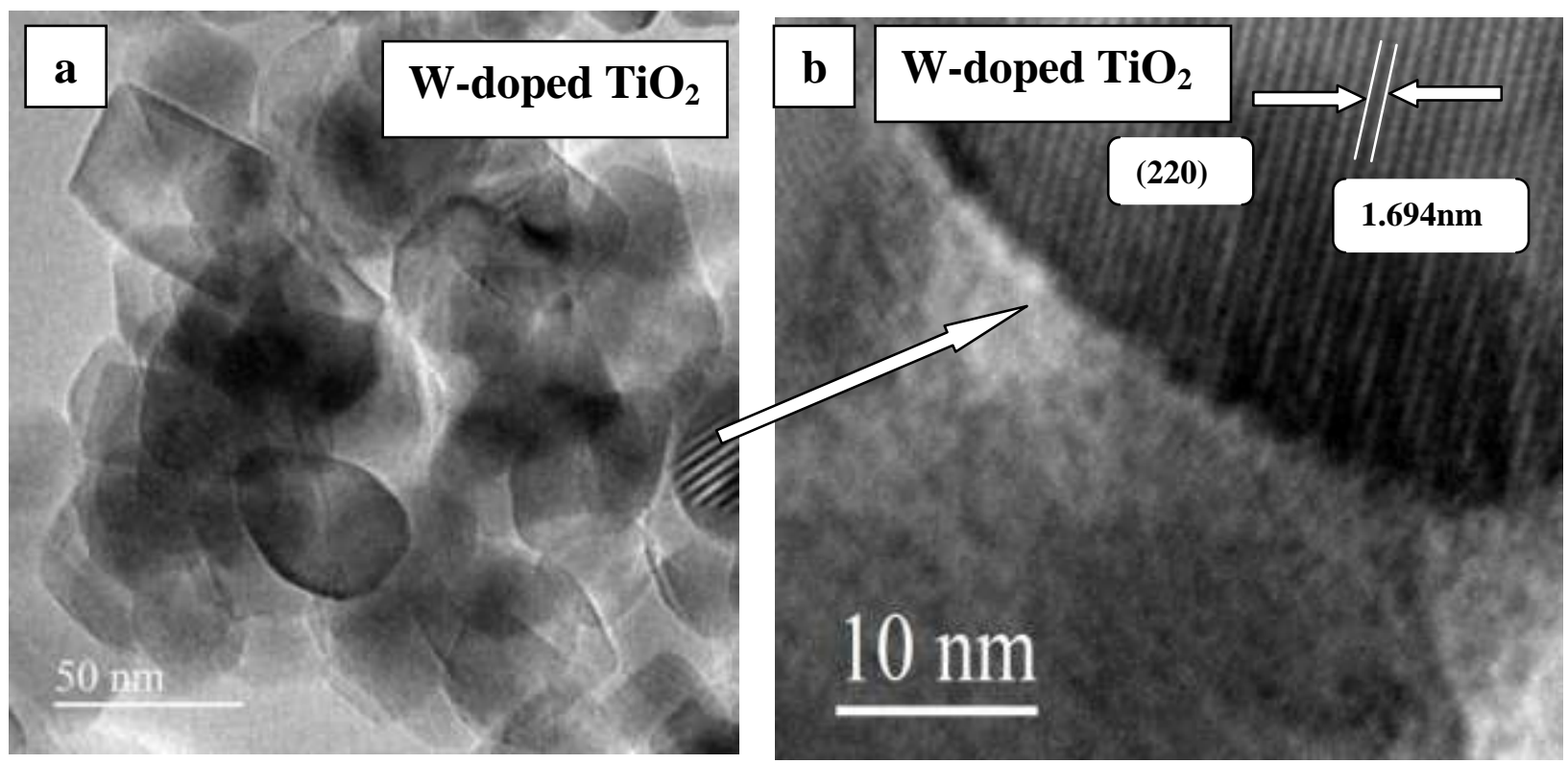

Figure $7 \mathrm{High}$ Resolution Transmission Electron Microscopy image of W-doped $\mathrm{TiO}_{2}$

The High Resolution TEM is used to study the morphology, distribution pattern, growth, of sample and it is also used to confirm the size of the particles. From the images clearly confirms that particles present in the W-doped $\mathrm{TiO}_{2}$ powdered sample is nanosized particles. HRTEM images shows, all the particles are in irregular shapes and agglomerated. The figure (b) shows presence of fringes which are identified by lattice d-spacing values of $1.694 \mathrm{~nm}$ which correspond to the lattice spacing values (220) by using the standard JCPDS data. 


\subsection{Antimicrobial activity}

(a) Staphylococcus aureus (Gram positive)

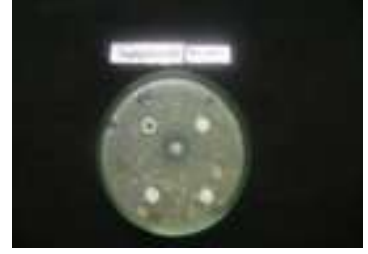

Pure $\mathrm{TiO}_{2}$ calcinated at $600^{\circ} \mathrm{C}$

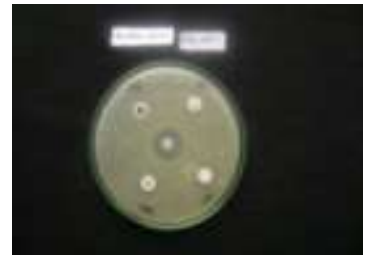

Pure $\mathrm{TiO}_{2}$ calcinated at $600^{\circ} \mathrm{C}$

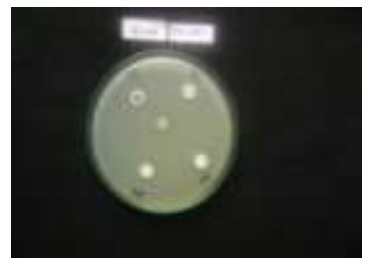

Pure $\mathrm{TiO}_{2}$ calcinated at $600^{\circ} \mathrm{C}$

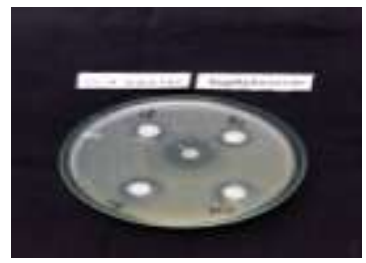

1 wt $\%$ W-doped $\mathrm{TiO}_{2}$

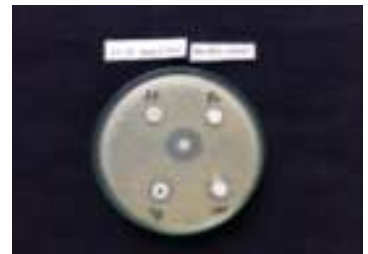

$1 \mathrm{wt} \%$ W-doped $\mathrm{TiO}_{2}$

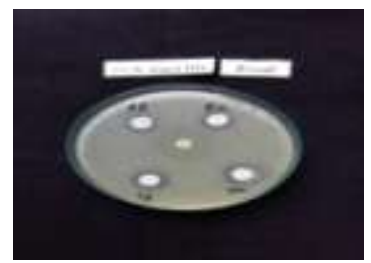

1 wt $\%$ W-doped $\mathrm{TiO}_{2}$

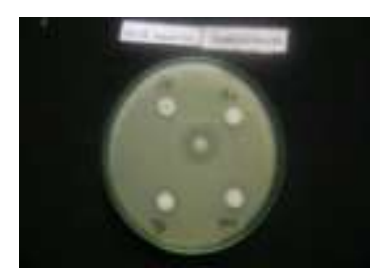

3 wt \% W-doped $\mathrm{TiO}_{2}$

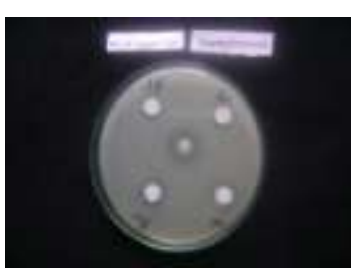

5 wt \% W-doped $\mathrm{TiO}_{2}$

(b)Bacillus subtilis (Gram positive)

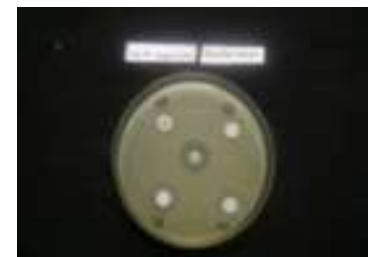

3 wt \% W-doped $\mathrm{TiO}_{2}$

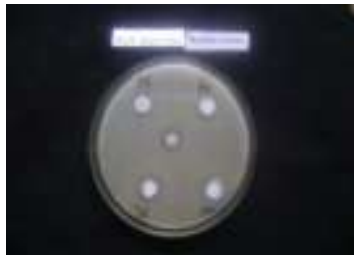

5 wt \% W-doped $\mathrm{TiO}_{2}$

(c) Escherichia coli (Gram negative)

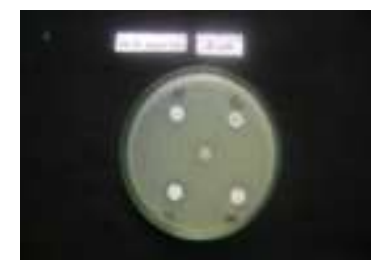

3 wt \% W-doped $\mathrm{TiO}_{2}$

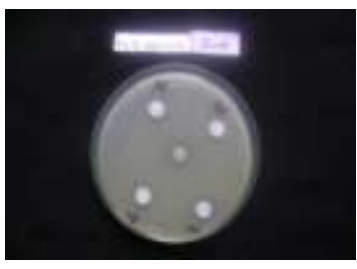

5 wt \% W-doped $\mathrm{TiO}_{2}$

(d) Pseudomonas aeruginosa (Gram negative)

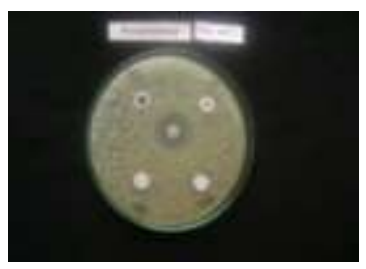

Pure $\mathrm{TiO}_{2}$ calcinated at $600^{\circ} \mathrm{C}$

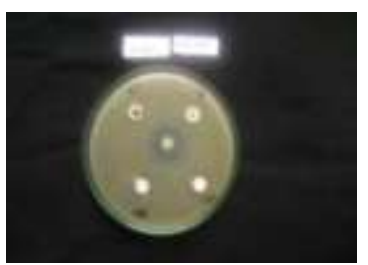

Pure $\mathrm{TiO}_{2}$ calcinated at $600^{\circ} \mathrm{C}$

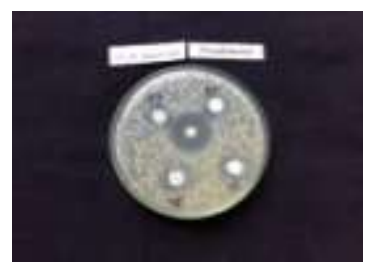

1 wt $\%$ W-doped $\mathrm{TiO}_{2}$

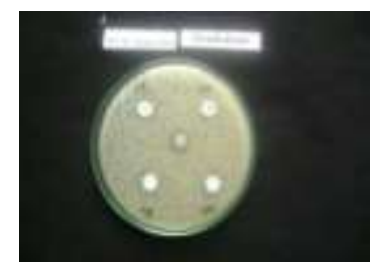

3 wt $\%$ W-doped $\mathrm{TiO}_{2}$

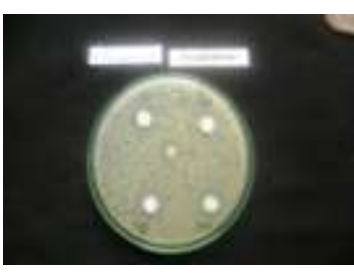

5 wt $\%$ W-doped $\mathrm{TiO}_{2}$

(e)Candida albicans (fungus)

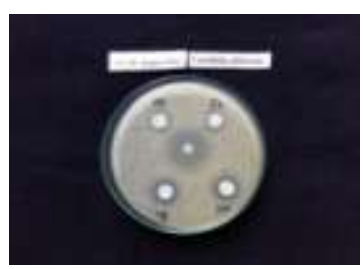

1 wt \% W-doped $\mathrm{TiO}_{2}$

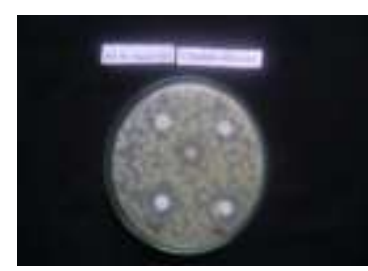

3 wt \% W-doped $\mathrm{TiO}_{2}$

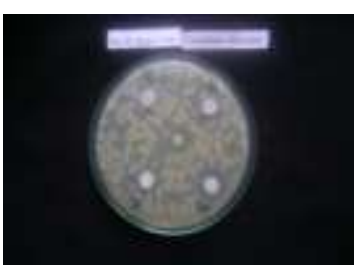

5 wt \% W-doped $\mathrm{TiO}_{2}$

(f) Aspergillus niger (fungus) 


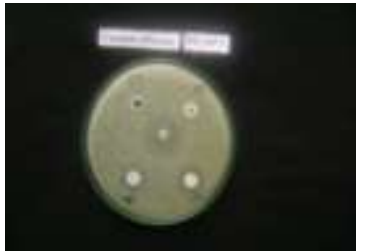

Pure $\mathrm{TiO}_{2}$ calcinated at $600^{\circ} \mathrm{C}$

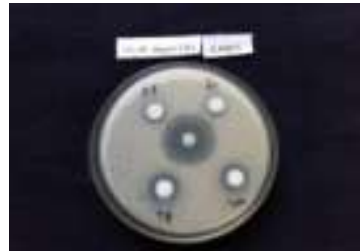

$1 \mathrm{wt} \% \mathrm{~W}$-doped $\mathrm{TiO}_{2}$

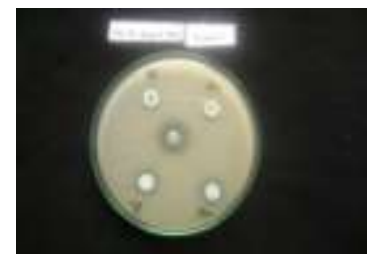

3 wt \% W-doped $\mathrm{TiO}_{2}$

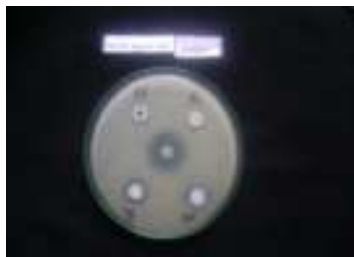

5 wt \% W-doped $\mathrm{TiO}_{2}$

Figure 7(a-f) Inhibition zone of different microorganism by media s subjected to pure $\mathrm{TiO}_{2}, 1 \mathrm{wt} \% \mathrm{~W}$ doped

$\mathrm{TiO}_{2}, 3 \mathrm{wt} \% \mathrm{~W}$-doped $\mathrm{TiO}_{2}, 5 \mathrm{wt} \% \mathrm{~W}$-doped $\mathrm{TiO}_{2}$ calcinated at $600^{\circ} \mathrm{C}$
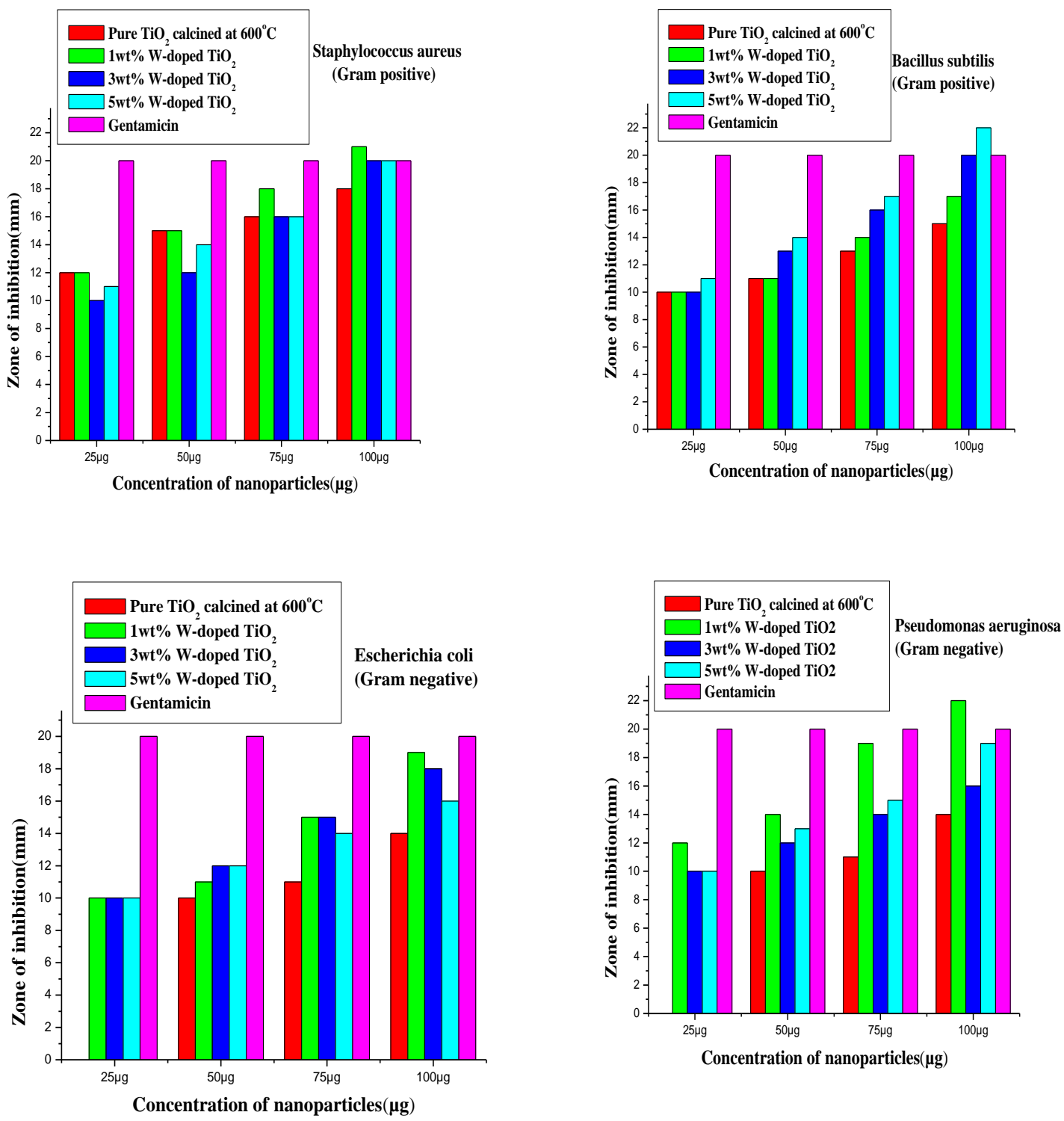

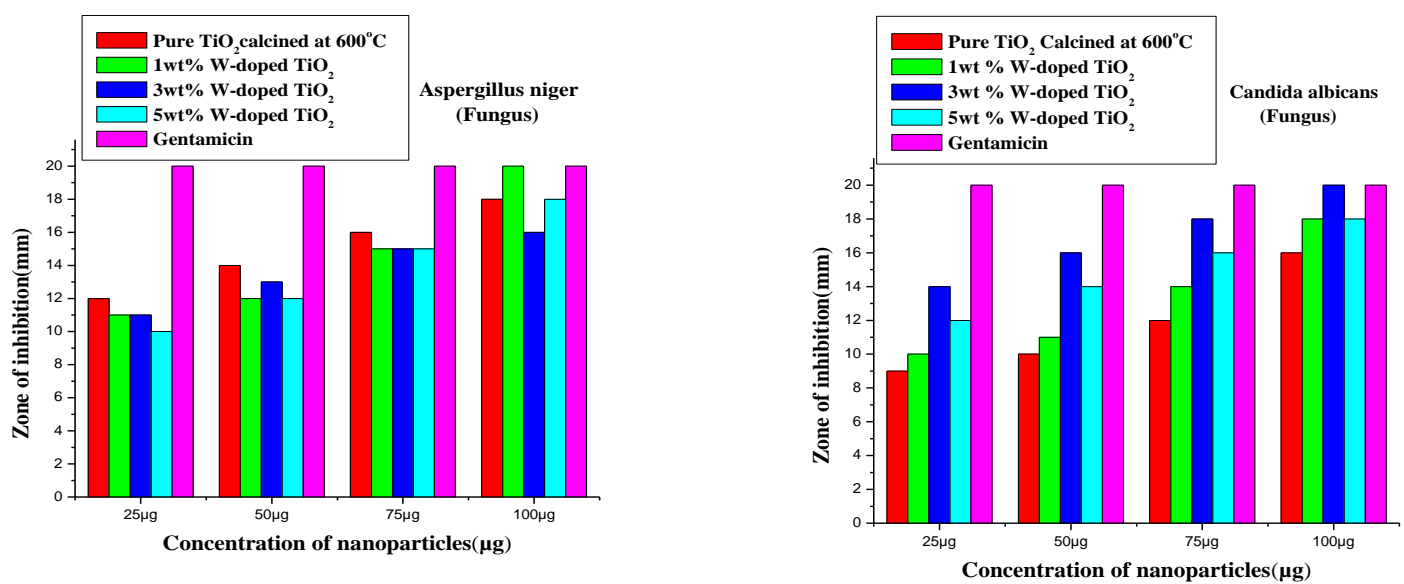

\section{Figure 8 Antibacterial effects of pure $\mathrm{TiO}_{2}, 1$ wt $\%$ W-doped $\mathrm{TiO}_{2}, 3$ wt $\%$ W-doped $\mathrm{TiO}_{2}$, and 5 wt $\%$ W-doped $\mathrm{TiO}_{2}$ calcinated at $600^{\circ} \mathrm{C}$}

The antimicrobial activities of the samples are identified from the zone of inhibition. The diameter of zone of inhibition was measured and expressed in millimeter. The results showed that for all of the four samples at different concentration showed some good zone of inhibition against all the pathogens used. In addition, it could be observed that the doped samples are having much higher zone of inhibition compared to the pure $\mathrm{TiO}_{2}$ sample. It shows that there is a significant effect of the tungsten induced antimicrobial activity for all the other doped samples. Also, the zone of inhibition increases as the concentration of the samples increases for almost all the samples against all the pathogens. However, none of the samples were able to reach the zone of inhibition of the standard Gentamicin except for the two samples which showed some higher zone of inhibition against the gram positive bacteria. The $1 \mathrm{wt} \% \mathrm{~W}$-doped $\mathrm{TiO}_{2}$ at higher concentration (100 $\mathrm{mg}$ ) showed a higher zone of inhibition against the gram positive bacteria Staphylococcus aureus compared to all other pure and doped samples. However the $3 \mathrm{wt} \%$ and $5 \mathrm{wt} \% \mathrm{~W}$-doped $\mathrm{TiO}_{2}$ showed the zone of inhibition to that of the standard Gentamicin. Similar results were observed for the $3 \mathrm{wt} \% \mathrm{~W}$-doped $\mathrm{TiO}_{2}$ against the gram positive bacteria Bacillus subtilis. $1 \mathrm{wt} \% \mathrm{~W}$-doped $\mathrm{TiO}_{2}$ at higher concentration showed a higher zone of inhibition compared to the standard Gentamicin against the gram negative bacteria Pseudomonas aeruginosa. These results proved that the effect of the W doping on $\mathrm{TiO}_{2}$ enhances the antimicrobial activity due to modified surface area, morphology and the reactivity of the samples.

\section{CONCLUSION}

Pure and $1 \mathrm{wt} \%, 3 \mathrm{wt} \%$ and $5 \mathrm{wt} \% \mathrm{~W}$-doped $\mathrm{TiO}_{2}$ nanoparticles were successfully synthesized by sol-gel method using hydroxylamine hydrochloride as a hydrolysis catalyst. The prepared nanoparticles are calcinated at $600^{\circ} \mathrm{C} \mathrm{for} 5 \mathrm{~h}$. According to the XRD pattern, $1 \mathrm{wt} \% \mathrm{~W}$-doped $\mathrm{TiO}_{2}$ was in an anatase crystalline form and it may be due to the smaller amount of $\mathrm{W}$ in $\mathrm{TiO}_{2}$. It did not affect the crystalline structure. Whereas $3 \mathrm{wt} \%$ and $5 \mathrm{wt} \% \mathrm{~W}$-doped $\mathrm{TiO}_{2}$ shows rutile crystalline structure which confirms the phase transformation due to the tungsten doping. The average particle sizes of pure $\mathrm{TiO}_{2}$ powder is approximately $37 \mathrm{~nm}$. The average particle size of $1 \mathrm{wt} \%, 3 \mathrm{wt} \%$, and $5 \mathrm{wt} \% \mathrm{~W}-\mathrm{TiO}_{2}$ powders are about $28 \mathrm{~nm}, 34 \mathrm{~nm}$ and $33 \mathrm{~nm}$ respectively. FESEM images of $1 \mathrm{wt} \% 3 \mathrm{wt} \%$ and $5 \mathrm{wt} \% \mathrm{~W}$-doped $\mathrm{TiO}_{2}$ which confirms the spherical with uniform sized particles and coherent together of all these nanoparticles. EDXA analysis shows that no impurities were present in the prepared pure and W-doped samples. UV-Vis absorbance spectra of doped $\mathrm{TiO}_{2}, 1 \mathrm{wt} \%$ W-doped $\mathrm{TiO}_{2}$ compared with other doped $3 \mathrm{wt} \%$ and $5 \mathrm{wt} \% \mathrm{TiO}_{2}$ samples observed redshift when increasing the doping concentration of tungsten The bandgap values of W-doping, decreases when increase in the doping of $\mathrm{W}$ content which shift to the longer wavelength. This may be attributed to the new electronic states and are introduced in the middle of the $\mathrm{TiO}_{2}$ bandgap after doping the $\mathrm{W}$ atoms $\mathrm{PL}$ spectrum indicates that the recombination of charge carriers is effectively reduced by the doping tungsten metal. From the HRTEM images spherical shaped particles are shown. But all the spherical shaped nanoparticles are agglomerated together to form a larger particle present in the nanostructure domain and particles size are approximately 30 to 35 . Broadening of peak of pure $\mathrm{TiO}_{2}$ in FTIR spectra is due to increasing the $\mathrm{W}$ doping. Antibacterial activity of the $\mathrm{W}$ doping on $\mathrm{TiO}_{2}$ enhances the antimicrobial activity due to modified surface area, morphology and the reactivity of the samples.

\section{References}

[1].M.R. Hoffmann, S.T. Martins, W. Choi, D.W. Bahnemann, Environmental Applications

of Semiconductor Photocatalysis Chem. Rev. 95 (1995) 69-96.

[2].A. Fujishima, T.N. Rao, D.A. Tryk, Titanium dioxide photocatalysis, J. Photochem.

Photobiol. C. 1 (2000) 1.

[3].Rajeshwar K, J. Appl. Electrochem .Photoelectrochemistry and the environment, 
25 (1995)1067-1082.

[4].S.D. Mo, W.Y. Ching, Phys. Rev. B Electronic and optical properties of three phases of titanium dioxide: Rutile, anatase, and brookite 51-19 (1995)13023.

[5].T. Putta, M.C. Lu, J. Anotai, Photocatalytic activity of tungsten-doped $\mathrm{TiO}_{2}$ with hydrothermal treatment under blue light irradiation, J. Environ. Manag. 92,(2011) 2272- 2276.

[6]. G. Ramis, G. Busca, C. Cristiani, L. Lietti, P. Forzatti, F. Bregani, Characterization of tungsta-titania catalysts Langmuir 8, (1992)1744- 1749.

[7].V.Stengl, J. Velicka, M. Marikova, T.M. Grygar, New Generation Photocatalysts: How Tungsten Influences the Nanostructure and Photocatalytic Activity of $\mathrm{TiO}_{2}$ in the UV and Visible Regions,ACS Appl. Mater. Interfaces 3, (2011)4014-4023.

[8].H. Yang, D. Zhang, L. Wang, Synthesis and characterization of tungsten oxide-doped titania nanocrystallites Mater. Lett. 57,(2002) 674-678.

[9].D.Byun, Y.Kim, K.Lee, P.Hofmann, Photocatalytic $\mathrm{TiO}_{2}$ deposition by chemical vapor deposition, Journal of Hazardous Materials, 73(2) (2000) 199-206.

[10].A.W.Bauer, M.M. Kirby,J.C. Sherris, M.Truck Antibiotic susceptibility testing by a standardized single disk method. Am J ClinPathol 45(1966) 493-496.

[11]. Zieli'nska A, Kowalska E, Sobczak JW, Łacka I, Gazda M, Ohtani B et al Silver-doped $\mathrm{TiO}_{2}$ prepared by microemulsion method: surface properties, bio- and photoactivity. Sep Purif Tech 72(2010) 309-318.

[12].T.V.L Thejaswini, N. Saraschandra, D. Prabhakaran, V.K. Indira Priyadharshini, Evaluation of Photocatalytic Activity of $\mathrm{Ag}$ I and $\mathrm{Sr}$ II co-doped $\mathrm{TiO}_{2}$ Nanoparticles for the Degradation of Reactive Blue-160 (RB-160) Textile Dye. International Journal of Advanced Chemical Science and Applications. Volume -2, Issue -2, (2014) 35-41.

[13]. A. Linsebigler, G. Lu, J.T. Yates, Photocatalysis on $\mathrm{TiO}_{2}$ Surfaces: Principles, Mechanisms, and Selected Results Chem. Rev. 95 (1995) 735.

[14]. Engweiler, J. Harf, A.Baiker, WOx/TiO 2 Catalysts Prepared by Grafting of Tungsten Alkoxides: Morphological Properties and Catalytic Behavior in the Selective Reduction of $\mathrm{NO}$ by $\mathrm{NH}_{3}$ J. Catal.159 (1996)259.

[15].S. Eibl, B.C. Gates, H. Knozinger, Structure of $\mathrm{WO}_{x} / \mathrm{TiO}_{2}$ Catalysts Prepared from HydrousTitanium Oxide Hydroxide: Influence of Preparation Parameters. Langmuir 17,(2001) 107- 115.

[16].S.A.K. Leghari, S. Sajjad, F. Chen, J.L. Zhang, $\mathrm{WO}_{3} / \mathrm{TiO}_{2}$ composite with morphology change via hydrothermal template-free route as an efficient visible light photocatalyst. Chem. Eng. J. 166,(2011) 906-915.

[17].P.S.Archana, Arunava Gupta, M.Mashitah. Yusoff and Rajan Jose, Tungsten doped titanium dioxide nanowires for high efficiency dye-sensitized solar cells.

[18]. Song, H. Jiang, H. Liu, X. Meng, G. J.Photochem. Photobiol, A, 2006, 181, $421-428$.

[19].W.Choi, A.Termin, M.R.Hoffmann, M. R. J. Phys. Chem. 1994, 98, 13669-13679.

[20].EkemenaOghenovohOseghea, Patrick GathuraNdungub, Sreekantha Babu Jonnalagaddaa, Photocatalytic degradation of 4-chloro-2-methylphenoxyacetic acid using $\mathrm{W}$-doped $\mathrm{TiO}_{2}$.

[21].S. Hu, F. Li and Z. Fan, Convenient Method to Prepare Ag Deposited N-TiO 2 Composite Nanoparticles via $\mathrm{NH}_{3}$ Plasma Treatment. Bull. Korean Chem. Soc. 33 (2012) 2309-2314.

[22].Y. L. Kuo, H. W. Chen and Y. Ku, Analysis of silver particles incorporated on $\mathrm{TiO}_{2}$ coatings for the photo decomposition of o-cresol.Thin Solid Films.515 (2007) 3461-3468.

[23].R.Velmurugan, B. Krishnakumar, B. Subashand, M. Swaminathan, Preparation and characterization of carbon nanoparticles loaded $\mathrm{TiO}_{2}$ and its catalytic activity driven by natural sunlight. Solar Energy Materials \& Solar Cells.108 ( 2013) 205-212.

[24].Xue Li, Yunyi Liu, Pengfei Yang, YongchaoShi College of Chemical Engineering, Shenyang University of Chemical Technology, Shenyang, Visible light-driven photocatalysis of W, N co-doped TiO2 110142, Chinaa- Particuology. 